Tijdschrift voor Economie en Management

Vol. LII, 4, 2007

\title{
Aggregate Bankruptcy Rates and the Macroeconomic Environment: Forecasting Systematic Probabilities of Default
}

\author{
by N. Dewaelheyns and C. Van Hulle*
}

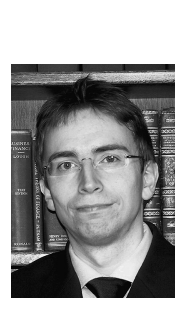

Nico Dewaelheyns

Department of Business Studies, Lessius University College

Affiliated Researcher

Research Center Finance,

Department of Accountancy,

Finance and Insurance (AFI),

Faculty of Business and

Economics, K.U.Leuven

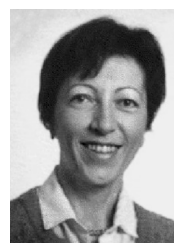

Cynthia Van Hulle

Research Center Finance,

Department of Accountancy,

Finance and Insurance (AFI),

Faculty of Business and

Applied Economics, K.U.Leuven

\footnotetext{
* Acknowledgements: the authors would like to thank an anonymous referee for useful comments and suggestions.
} 


\begin{abstract}
Recent empirical research has stressed the importance of economy wide factors in the assessment of default risk, for instance for bond portfolios or portfolios of bank loans. Macroeconomic risk is essentially systematic, as it is difficult to reduce through diversification. Adequate forecasts of the links between macroeconomic factors and default risk, often defined as aggregate credit risk, are therefore important in a large number of risk management applications. This paper considers eleven alternative ways to model the aggregate bankruptcy rate, which is a proxy for aggregate credit risk, on Belgian data for the period 19862002. Based on these models, forecasts of the bankruptcy rates for 2003-2006 are made and compared. Four or five-variable Almon lag models result in the best in-sample fit and have the best forecast performance, but much more straightforward alternatives - such as an ARMA model or a one-variable model based on real GDP growth - do almost equally well. Four or five-variable vector error correction models are shown to have good in-sample fit, but very poor out-of-sample forecasting power. Overall we find that the prediction power of simple models is hard to beat.
\end{abstract}

Recent empirisch onderzoek besteedt veel aandacht aan het belang van macroeconomische factoren voor het schatten van default risico in, bijvoorbeeld, obligatieportefeuilles of portefeuilles van bankleningen. Macro-economisch risico is een vorm van systematisch risico, aangezien het heel moeilijk te reduceren is door diversificatie. Goede voorspellingen van het verband tussen macroeconomische factoren en default risico, vaak gedefinieerd als geaggregeerd kredietrisico, zijn daarom van belang voor een groot aantal risk management toepassingen. In deze paper modelleren we - op elf verschillende manieren - de Belgische geaggregeerde faillissementsgraad (een proxy voor geaggregeerd kredietrisico) voor de periode 1986-2002. We gebruiken die modellen om de faillissementsgraden voor 2003-2006 te voorspellen. Almon lag modellen met vier of vijf variabelen hebben de beste fit binnen de steekproef en de beste voorspellingskracht, maar veel eenvoudigere alternatieven (zoals een ARMA model of een model enkel gebaseerd op de groei van het reële BNP) doen het bijna even goed. Een vector error correction model met vier of vijf variabelen heeft een goede fit binnen de steekproef, maar is zeer zwak qua voorspellingskracht. In het algemeen kunnen we concluderen dat de voorspellingskracht van eenvoudige modellen moeilijk te overtreffen valt. 


\section{INTRODUCTION}

A growing body of recent empirical research has shown that many credit risk measures such as probability of default (PD), loss given default (LGD) or exposure at default (EAD) are procyclical, i.e. dependent upon the general state of the economy (Allen and Saunders (2004)). Moreover, macroeconomic risk components are systematic as they are present for all companies within an economy so that exposure to this risk cannot be meaningfully reduced through diversification across industries or firm types in a domestic portfolio. ${ }^{1}$ Adequate forecasts of the links between macroeconomic factors and default risk, often defined as aggregate default risk, are therefore useful in a large number of risk management applications, including corporate failure prediction and the determination of bank capital requirements.

In this paper, novel to the literature, we explicitly consider and compare eleven alternative ways to model the aggregate bankruptcy rate, which can be seen as a proxy for aggregate default risk (cf. Koopman and Lucas (2005)). In contrast to virtually all existing academic research which focuses on the U.S. or the U.K., we estimate the models on Belgian data for the period 1986-2002, thus adding to the scarce empirical evidence of these issues for continental European economies. ${ }^{2}$ More importantly however, as in practice the model parameters are used to predict future bankruptcy rates, we also evaluate the out-of-sample prediction capacity for the period 2003-2006. Previewing our main results, four or five-variable Almon lag models result in the best in-sample fit and have the best forecast performance, but much more straightforward alternatives - such as an ARMA model or a one-variable model based on real GDP growth - do almost equally well. Four or five-variable vector error correction models are shown to have good in-sample fit, but very poor out-of-sample forecasting power. Overall however, from the perspective of out-of-sample prediction ability, simple models tend to be the best performers. This finding casts doubt on the capacity of more sophisticated models to add to out-of-sample predictive accuracy.

The remainder of the paper is structured as follows: Section II contains an overview of the related literature; Section III briefly summarizes the main methodological issues; Section IV describes the data; tests and results are discussed in Section V and Section VI concludes. 


\section{RELATED LITERATURE}

The empirical literature on the relationships between macroeconomic variables and the aggregate bankruptcy rate or aggregate default rate can be split up into three main categories. ${ }^{3}$ The first and oldest part of the literature simply explores the nature of the links between different types of macroeconomic variables and aggregate failure rates. The results of these types of models can be interpreted as evidence of transmission mechanisms and be used in formulating recommendations about, for instance, monetary policy. The seminal paper in this field is Altman (1983), which is the first to empirically model the relationships between bankruptcy rates and general macroeconomic conditions. Altman (and many others, including e.g. Hudson (1986) or Ilmakunnas and Topi (1999)) finds that general business cycle indicators, such as GDP growth, are negatively related to aggregate failure rates. There is also evidence concerning many other types of macroeconomic variables such as aggregate corporate birth rates (e.g. Hudson (1986); Johnson and Parker (1994)), inflation (Wadhwani (1986)), exchange rates (Vlieghe (2001)), unemployment (Hudson (1997)), wage levels (Chen and Williams (1999)) or interest rates (Liu and Wilson (2002)). Recent examples of this kind of exploratory research include Liu (2004) for the U.K. and Gaffeo and Santoro (2006) for Italy. The link between macroeconomic conditions and business failures is also supported by survey evidence: Sullivan et al. (1999) document that outside business conditions are the most mentioned reasons for the bankruptcy of U.S. small firms, confirming earlier results by e.g. Peterson et al. (1983). For Belgium, surveys by credit data provider Graydon show that owners and managers of failed businesses as well as bankruptcy judges point to bad general economic conditions as a major cause of bankruptcy (Graydon Belgium (2002), (2003)).

The second class of empirical research focuses on the impact of institutional factors on aggregate failure rates. In general, these papers control for macroeconomic conditions in order to study the effect of e.g. a legal or policy reform. For instance, Turner et al. (1992) show that the policies of the Thatcher government in the early 1980s strongly increased the business cycle sensitivity of corporate liquidations. Concerning the 1978 U.S. Bankruptcy Reform Act, Boyes and Faith (1986) find that the reform increased the number 
of corporate bankruptcy filings, while Domowitz and Eovaldi (1993) and Nelson (2000) show that use of the personal bankruptcy procedure (the so-called Chapter 13 procedure) significantly increased after the introduction of the Act. Fisher and Martel (2003) show that the 1992 Canadian bankruptcy reform stimulated the number of filed corporate reorganization proposals. Cuthbertson and Hudson (1986), Vlieghe (2001), Liu and Wilson (2002) and Liu (2004) find a significant decrease in the corporate liquidation rate after implementation of the U.K.'s 1986 Insolvency Act. A similar effect is found by Dewaelheyns and Van Hulle (2008) for the 1997 Belgian bankruptcy reform and small and micro business bankruptcy rates, although the beneficial impact is limited to certain industry groups (most notably manufacturing and trade companies), indicating that not all aspects of the reform are equally useful for different types of companies.

The final, fast growing research area examines the importance of macroeconomic factors for credit risk assessment and management. The main idea in this literature is that systematic risk factors (i.e. macroeconomic risk) are correlated with probability of default (PD), loss given default (LGD) and exposure at default (EAD), and are therefore relevant for, for instance, bank capital requirements; see Allen and Saunders (2004) for a survey. Koopman and Lucas (2005) show that there are cycles of credit risk using the annual U.S. business failure rate during the period 1933-1997 as a proxy for default risk. Helwege and Kleiman (1997) and McDonald and Van de Gucht (1997) show that macroeconomic conditions matter for high yield bond default rates. Pesaran et al. (2006) model risk in a credit portfolio using a global macroeconomic model, based on countrylevel vector error correction models linking variables as GDP, stock prices, inflation, exchange rates, etc. Finally, an increasing number of papers adds macroeconomic variables to corporate failure prediction models, either building on traditional accounting data driven models (following e.g. Altman (1968) or Ohlson (1980)), or extending distance to default models. For U.S. and U.K. quoted companies, variables such as the lagged aggregate bankruptcy rate (Hillegeist et al. (2004)), the lagged stock market performance (Duffie et al. (2007)), interest rates (e.g. Hunter and Isachenkova (2006)), price changes (e.g. Bhattacharjee et al. (2005)) and real GDP growth (Drehmann et al. (2006)) have been shown to be related to corporate failure probabilities. 


\section{METHODOLOGY}

One of the most well-documented problems in working with macroeconomic time series data is the fact that many macroeconomic variables are integrated of order one (i.e. they contain a unit root), making the use of standard time series techniques inappropriate. The straightforward solution to this is to difference all series to make them stationary, which is why all models in this paper are estimated in first differences. Specifically, we consider two econometric methods which have been regularly applied in the literature: a distributed lag model (e.g. Altman (1983), Vlieghe (2001), Dewaelheyns and Van Hulle (2008)) and a vector error correction model (e.g. Liu and Wilson (2002), Liu (2004), Gaffeo and Santoro (2006)).

\section{Almon Polynomial Distributed Lag Models}

One of the widespread methodologies in the aggregate failure rate literature from Altman (1983) onwards assumes that the corporate bankruptcy rate $(\mathrm{BR})$ is a function of a number of macroeconomic variables, which can be expressed as a finite distributed lag (FDL) model:

$$
B R_{t}=a+\sum_{i=0}^{k} \beta_{1, t-i} X_{1, t-i}+\sum_{i=0}^{k} \beta_{2, t-i} X_{2, t-i}+\ldots+\varepsilon_{t}
$$

where: $k=$ maximum lag length

$X=$ macroeconomic variable

$\varepsilon=$ error term

The direct estimation of such a model results in multicollinearity problems between different lagged variables and is costly in terms of degrees of freedom. Both issues can be addressed by an Almon polynomial distributed lag (PDL) specification. It can be shown that any $\beta_{i}$ in equation (1) can be approximated by a polynomial of order $m$ :

$$
\beta_{i}=b_{0}+b_{1} i+b_{2} i^{2}+\ldots+b_{m} i^{m}
$$

Substituting (2) into (1) leads to:

$$
B R_{t}=a+\sum_{j=1}^{l} b_{j, 0 t} Z_{j, 0 t}+\sum_{j=1}^{l} b_{j, 1 t} Z_{j, 1 t}+\ldots+\sum_{j=1}^{l} b_{j, m t} Z_{j, m t}+\varepsilon_{t}
$$


where: $l=$ number of macroeconomic variables

$$
\begin{aligned}
& Z_{j, 0 t}=\sum_{i=0}^{k} X_{j, t-i} \\
& Z_{j, t t}=\sum_{i=0}^{k} i X_{j, t-i} \\
& Z_{j, m t}=\sum_{i=0}^{k} i^{m} X_{j, t-i}
\end{aligned}
$$

OLS will lead to best linear unbiased estimators in equation (3) as long as $\varepsilon$ fulfils the standard least squares assumptions (Gujarati, (1995)). Individual $\beta$ coefficients from equation (1) can then be computed from the polynomials. The sum of these $\hat{\beta}$ s reflects the long run relationship between the macroeconomic variable and the bankruptcy rate.

\section{Vector Error Correction Models (VECM)}

It can be argued that first differencing is done at the cost of losing information which may be contained in the levels of the data, and that if a number of variables are cointegrated differencing the relationship results in a misspecification error (Enders, (1995)). If a number of non-stationary series are cointegrated, a linear combination of these series can be found which is stationary. In essence, this means that there is a long run equilibrium between the different series. This long run equilibrium can be estimated as a static model (the cointegrating equation):

$$
\beta_{1} B R_{t}+\sum_{i=0}^{l} \beta_{i} X_{i, t}+e_{t}=0
$$

where: $l=$ number of macroeconomic variables

$X=$ macroeconomic variable

$e=$ equilibrium error

An error correction model is based on the fact that deviations from the long run equilibrium should be reduced through time. The short run 
dynamics of the relationships between the cointegrated variables can then be expressed as a system of equations:

$$
\left[\begin{array}{c}
\Delta B R_{t} \\
\Delta X_{1, t} \\
\vdots \\
\Delta X_{l, t}
\end{array}\right]=\left[\begin{array}{c}
\gamma_{0,0} \\
\gamma_{0,1} \\
\vdots \\
\gamma_{0, l}
\end{array}\right]+\left[\begin{array}{c}
a_{0} \\
a_{1} \\
\vdots \\
a_{l}
\end{array}\right]\left[E C_{t-1}\right]+\sum_{i=l}^{k}\left[\begin{array}{cccc}
\gamma_{0,0}^{i} & \gamma_{1,0}^{i} & \ldots & \gamma_{l, 0}^{i} \\
\gamma_{0,1}^{i} & \gamma_{1,1}^{i} & \ldots & \gamma_{l, 1}^{i} \\
\vdots & \vdots & \ddots & \vdots \\
\gamma_{0, l}^{i} & \gamma_{1, l}^{i} & \cdots & \gamma_{l, l}^{i}
\end{array}\right]\left[\begin{array}{c}
\Delta B R_{t-i} \\
\Delta X_{1, t-i} \\
\vdots \\
\Delta X_{l, t-i}
\end{array}\right]+\left[\begin{array}{c}
\varepsilon_{0, t} \\
\varepsilon_{1, t} \\
\vdots \\
\varepsilon_{l, t}
\end{array}\right]
$$

where: $E C_{t-i}=$ deviation from the long run equilibrium in the previous period, based on the cointegrating equation estimated in (4)

$l=$ number of macroeconomic variables

$X=$ macroeconomic variable

$k \quad=$ maximum lag length

$\alpha=$ speed of adjustment towards long run equilibrium

$\varepsilon \quad=$ error term

\section{DATA}

All Belgian limited liability companies have an obligation to annually deposit financial statements at the National Bank of Belgium (NBB). These companies are included in the NBB legal status database, which records the exact date of all start-ups, voluntary liquidations, mergers $\&$ acquisitions, bankruptcies, formal reorganizations, etc. On the basis of the information in the legal status database and data from business credit information provider Graydon Belgium, we compute aggregate bankruptcy rates - as a proxy for aggregate default risk - based on the number of stock corporations (NV/SA) that entered a bankruptcy procedure in a specific quarter of the period 1986-2006 (total of 24,490 bankruptcy cases), and the total number of registered stock corporations at the beginning of that quarter. ${ }^{4}$

Based on the literature discussed in Section II, we select a number of macroeconomic variables that have been shown to be related to the aggregate failure rate: real GDP growth, the OECD euro-zone Composite Leading Indicator (CLI), inflation (based on the consumer price index), stock market performance (based on the Belgian All Shares Index) and the aggregate corporate birth rate. ${ }^{5}$ The corporate birth rate 
is computed completely analogously to the bankruptcy rate, with data from the same sources. The other macroeconomic time series are collected from the IMF international financial statistics (GDP levels), the OECD (CLI) and Belgostat (inflation and Belgian All Shares stock index). When relevant, the series are seasonally adjusted using the Census X12 method.

Unit root tests for all variables are reported in Table 1. For the levels of the explanatory variable series (real GDP, CLI, consumer price index, Belgian All Shares Index, aggregate birth rate) the null hypothesis of a unit root cannot be rejected, neither by an Augmented Dickey-Fuller (ADF) test, nor by a Phillips-Perron (PP) test. The test score reported for the dependent variable (aggregate bankruptcy rate) controls for the presence of a structural break in the series at the time of the introduction of the new bankruptcy legislation (during the first quarter of 1998) using Perron's (1989) technique and critical values. Again, the null hypothesis of a unit root cannot be rejected.

TABLE 1

Unit Root Tests

\begin{tabular}{lcccc}
\hline & \multicolumn{2}{c}{ Levels } & \multicolumn{2}{c}{ First Differences } \\
\cline { 2 - 5 } & ADF & PP & ADF & PP \\
\hline Bankruptcy rate & - & -3.516 & - & $-8.811^{* * *}$ \\
$\ln ($ real GDP) & -2.833 & -2.311 & $-4.299^{* * *}$ & $-4.457^{* * *}$ \\
$\ln ($ Belgian All Shares Index) & -1.409 & -1.347 & $-9.207^{* * *}$ & $-9.243^{* * *}$ \\
$\ln ($ Consumer Price Index $)$ & -1.800 & -0.944 & $-9.066^{* * *}$ & $-9.006^{* * *}$ \\
Euro-zone Composite Leading & & & & \\
Indicator & -2.390 & -2.246 & $-4.876^{* * *}$ & $-3.653^{* *}$ \\
Corporate birth rate & -2.635 & -2.637 & $-9.071^{* * *}$ & $-9.039^{* * *}$ \\
\hline
\end{tabular}

ADF: Augmented Dickey-Fuller test; PP: Phillips-Perron test; all test equations include a trend and intercept; ADF: lag length selection based on Schwartz Information Criterion; PP: Newey-West bandwidth selection; rejection of null hypothesis of unit root based on MacKinnon critical values; Bankruptcy rate: Perron (1989) test controlling for structural break in 1998Q1, rejection of null hypothesis of unit root based on Perron (1989) critical values; Sample period 1986Q12002Q4; ${ }^{* * *}$ denotes significance at the $1 \%$ level; ${ }^{* *}$ denotes significance at the $5 \%$ level; * denotes significance at the $10 \%$ level. 


\section{TESTS AND RESULTS}

\section{A. Modeling the aggregate bankruptcy rate}

In total, we consider eleven different model specifications to explain changes in the aggregate stock corporation bankruptcy rate for a sample period of 1986Q1-2002Q4: four extensive time series models containing multiple macroeconomic variables (two Almon lag models and two Vector Error Correction Models), six simpler alternatives based on only one macroeconomic series and a Box-Jenkins model which does not take into account macroeconomic variables at all. These models will be used to construct forecasts in the next subsection.

The first model is an Almon polynomial distributed lag (PDL) model which contains the four domestic macroeconomic variables we use in this paper: real GDP growth, stock market performance, changes in inflation and changes in the corporate birth rate. We include changes in inflation ( $\Delta$ inflation) as Wadhwani (1986) argues that changes are likely to reflect more information about macroeconomic conditions and outlook than the level of inflation. To capture potential autocorrelation in the changes in bankruptcy rates, we also include lagged bankruptcy rate changes. Based on fit criteria, the lag length of all PDL terms is set to nine periods (i.e. nine quarters) and the order of the polynomial to three. The $\hat{\beta}$ s (i.e. the individual lag coefficients computed from the polynomials) are reported in Table 2 . The sums of the $\hat{\beta}$ s, which can be interpreted as the overall relationship between the macroeconomic variable and the aggregate bankruptcy rate assuming longer lag length coefficients are equal to zero, are reported as well.

The sum of lags is significantly negatively related to changes in bankruptcy rates for four out of five variables. For stock market performance this relationship is straightforward: strong market performance reflects a positive economic outlook, which is linked to fewer bankruptcies. The negative relationship with changes in inflation is in line with e.g. Altman (1983), who argues that rising inflation creates breathing room for struggling companies, for instance by passing higher input prices through to consumers and by reducing labor costs, although the latter effect should be less important in Belgium due to the automatic indexation of wages. As far as the corporate birth rate is concerned, the negative relationship with bankruptcy rates suggests that the beneficial multiplier effects of corporate births, discussed in 
TABLE 2

Almon Lag Model I

\begin{tabular}{|c|c|c|c|c|c|}
\hline & $\begin{array}{l}\text { Real GDP } \\
\text { Growth }\end{array}$ & $\begin{array}{c}\text { Stock } \\
\text { Market } \\
\text { Performance }\end{array}$ & $\Delta$ Inflation & $\begin{array}{c}\Delta \text { Corporate } \\
\text { Birth Rate }\end{array}$ & $\begin{array}{c}\Delta \text { Bankruptcy } \\
\text { Rate }\end{array}$ \\
\hline $\operatorname{Lag}(1)$ & $\begin{array}{c}-0.6659^{*} \\
(1.853)\end{array}$ & $\begin{array}{c}-0.1345^{* * *} \\
(3.373)\end{array}$ & $\begin{array}{c}-1.3924^{*} \\
(1.947)\end{array}$ & $\begin{array}{c}-0.0286^{* *} \\
(2.075)\end{array}$ & $\begin{array}{c}-0.2627^{* *} \\
(2.134)\end{array}$ \\
\hline $\operatorname{Lag}(2)$ & $\begin{array}{c}-0.2491 \\
(1.363)\end{array}$ & $\begin{array}{c}-0.0472^{* *} \\
(2.469)\end{array}$ & $\begin{array}{c}-0.5585 \\
(1.591)\end{array}$ & $\begin{array}{c}-0.0237^{* *} \\
(2.332)\end{array}$ & $\begin{array}{c}-0.2594^{* * *} \\
(3.397)\end{array}$ \\
\hline $\operatorname{Lag}(3)$ & $\begin{array}{c}0.0272 \\
(0.172)\end{array}$ & $\begin{array}{r}-0.0034 \\
(0.154)\end{array}$ & $\begin{array}{r}-0.1694 \\
(0.509)\end{array}$ & $\begin{array}{c}-0.1694^{*} \\
(1.933)\end{array}$ & $\begin{array}{c}-0.2505^{* * *} \\
(2.982)\end{array}$ \\
\hline $\operatorname{Lag}(4)$ & $\begin{array}{c}0.1866 \\
(1.168)\end{array}$ & $\begin{array}{c}0.0079 \\
(0.356)\end{array}$ & $\begin{array}{r}-0.1071 \\
(0.299)\end{array}$ & $\begin{array}{c}-0.0138 \\
(1.548)\end{array}$ & $\begin{array}{c}-0.2356^{* *} \\
(2.547)\end{array}$ \\
\hline $\operatorname{Lag}(5)$ & $\begin{array}{c}0.2525 \\
(1.667)\end{array}$ & $\begin{array}{r}-0.0025 \\
(0.142)\end{array}$ & $\begin{array}{r}-0.2538 \\
(0.752)\end{array}$ & $\begin{array}{r}-0.0093 \\
(1.188)\end{array}$ & $\begin{array}{c}-0.2143^{* *} \\
(2.175)\end{array}$ \\
\hline $\operatorname{Lag}(6)$ & $\begin{array}{c}0.2484 \\
(1.551)\end{array}$ & $\begin{array}{r}-0.0238 \\
(1.428)\end{array}$ & $\begin{array}{r}-0.4918 \\
(1.506)\end{array}$ & $\begin{array}{r}-0.0053 \\
(0.718)\end{array}$ & $\begin{array}{c}-0.1864^{*} \\
(1.716)\end{array}$ \\
\hline $\operatorname{Lag}(7)$ & $\begin{array}{c}0.1976 \\
(1.056)\end{array}$ & $\begin{array}{c}-0.0450^{* *} \\
(2.077)\end{array}$ & $\begin{array}{c}-0.7033^{* *} \\
(1.998)\end{array}$ & $\begin{array}{r}-0.0022 \\
(0.274)\end{array}$ & -0.1514 \\
\hline $\operatorname{Lag}(8)$ & $\begin{array}{c}0.1236 \\
(0.632)\end{array}$ & $\begin{array}{c}-0.0554^{* *} \\
(2.215)\end{array}$ & $\begin{array}{c}-0.7703^{* *} \\
(2.143)\end{array}$ & $\begin{array}{r}-0.0001 \\
(0.010)\end{array}$ & $\begin{array}{r}-0.1089 \\
(0.961)\end{array}$ \\
\hline $\operatorname{Lag}(9)$ & $\begin{array}{c}0.0499 \\
(0.344)\end{array}$ & $\begin{array}{c}-0.0440^{* *} \\
(2.248)\end{array}$ & $\begin{array}{c}-0.5752^{* *} \\
(2.154)\end{array}$ & $\begin{array}{c}0.0072 \\
(0.125)\end{array}$ & $\begin{array}{r}-0.0585 \\
(0.741)\end{array}$ \\
\hline Sum of lags & $\begin{array}{c}0.1709 \\
(0.135)\end{array}$ & $\begin{array}{c}-0.3480^{* * *} \\
(4.812)\end{array}$ & $\begin{array}{c}-2.2207^{*} \\
(1.987)\end{array}$ & $\begin{array}{c}-0.1010^{* *} \\
(2.594)\end{array}$ & $\begin{array}{c}-1.7275^{* *} \\
(2.673)\end{array}$ \\
\hline $\begin{array}{l}\text { Code change } \\
\text { dummy } \\
\text { Intercept }\end{array}$ & $\begin{array}{c}-0.0476^{* * *} \\
(7.006) \\
0.0359^{* * *} \\
(6.252)\end{array}$ & & & & \\
\hline $\mathrm{R}^{2}$ & 0.7836 & & & & \\
\hline Adjusted $\mathrm{R}^{2}$ & 0.6925 & & & & \\
\hline AIC & -13.3143 & & & & \\
\hline
\end{tabular}

Almon polynomial distributed lag (PDL) model; Dependent variable: 1-yr change in quarterly aggregate stock corporation bankruptcy rate; t-statistics in parentheses (HAC); reported coefficients ares; Sample period 1986Q1-2002Q4; Code change dummy: 0 from 1986Q1 to 1997Q4, 1 afterwards; AIC = Akaike Information Criterion; ${ }^{* * *}$ denotes significance at the $1 \%$ level; ${ }^{* *}$ denotes significance at the $5 \%$ level; ${ }^{*}$ denotes significance at the $10 \%$ level. 
Johnson and Parker (1994) (i.e. new company formations increase overall business activity and create opportunities) outweigh the negative ones (i.e. many companies fail soon after start-up). In this sense, the corporate birth rate can also be interpreted as a general business cycle indicator. Finally, the negative sign for lagged changes in bankruptcy rates implies that a rise (fall) in bankruptcy rates in the past makes future increases (decreases) less likely. The sum of lags for real GDP growth is not significantly different from zero. In fact, only the coefficient for the first lag of real GDP growth is significantly negative (at the $10 \%$ level). This could be due to the fact that several of the other macroeconomic variables contain information on the general state of the economy of which GDP growth is a proxy. ${ }^{6}$ For instance, during our sample period, stock market return is a relatively good leading indicator of GDP growth. However, robustness checks ${ }^{7}$ show that excluding the stock market return from the models has a negative effect on both model fit and predictive ability.

The final variable (except for the intercept) reported in Table 2 is a jump dummy variable which controls for the impact of the 1997 bankruptcy reform. Chow breakpoint tests point to the presence of a structural break around the introduction of the legislative framework at the beginning of 1998. The partial structural break specification (i.e. allowing for a change in the intercept and assuming the other coefficients remained stable after the break) is the approach usually followed in the literature (see for instance Vlieghe (2001); Liu and Wilson (2002) or Liu (2004)). The alternative is a pure structural break model, which has the advantage that it allows all coefficients to change, but has the drawback of being very costly in terms of degrees of freedom. Robustness checks reported in Dewaelheyns and Van Hulle (2008) indicate that the code change dummy is an adequate break correction. The code change dummy is included in all models in this paper and is always highly significantly negative, which implies that the aggregate bankruptcy rate in the post-reform period is lower than one would expect given the macroeconomic environment (see Dewaelheyns and Van Hulle (2008) for a full discussion of these issues).

An alternative, more parsimonious Almon lag model is reported in Table 3. This model uses changes in the OECD euro-zone Composite Leading Indicator (CLI) - which is less correlated with the other explanatory variables in the model - instead of real GDP growth. We no longer include changes in inflation, as robustness checks show this 
TABLE 3

Almon Lag Model II

\begin{tabular}{|c|c|c|c|c|}
\hline & $\begin{array}{l}\Delta \text { Euro-zone } \\
\text { Composite } \\
\text { Leading } \\
\text { Indicator }\end{array}$ & $\begin{array}{c}\text { Stock } \\
\text { Market } \\
\text { Performance }\end{array}$ & $\begin{array}{c}\Delta \text { Corporate } \\
\text { Birth Rate }\end{array}$ & $\begin{array}{c}\Delta \text { Bankruptcy } \\
\text { Rate }\end{array}$ \\
\hline $\operatorname{Lag}(1)$ & $\begin{array}{c}-0.3641^{*} \\
(1.687)\end{array}$ & $\begin{array}{c}-0.1571^{* * *} \\
(5.942)\end{array}$ & $\begin{array}{r}-0.0107 \\
(1.158)\end{array}$ & $\begin{array}{c}-0.4774^{* * *} \\
(3.935)\end{array}$ \\
\hline Lag (2) & $\begin{array}{c}-0.2967^{* * *} \\
(2.763)\end{array}$ & $\begin{array}{c}-0.0495^{* * *} \\
(4.828)\end{array}$ & $\begin{array}{c}-0.0211^{* * *} \\
(3.433)\end{array}$ & $\begin{array}{c}-0.3741^{* * *} \\
(5.430)\end{array}$ \\
\hline Lag (3) & $\begin{array}{c}-0.2022^{* *} \\
(1.925)\end{array}$ & $\begin{array}{c}0.0070 \\
(0.801)\end{array}$ & $\begin{array}{c}-0.0259^{* * *} \\
(4.220)\end{array}$ & $\begin{array}{c}-0.3086^{* * *} \\
(6.167)\end{array}$ \\
\hline Lag (4) & $\begin{array}{c}-0.1049^{* *} \\
(2.054)\end{array}$ & $\begin{array}{l}0.0244^{* *} \\
(2.484)\end{array}$ & $\begin{array}{c}-0.0262^{* * *} \\
(5.930)\end{array}$ & $\begin{array}{c}-0.2651^{* * *} \\
(5.969)\end{array}$ \\
\hline $\operatorname{Lag}(5)$ & $\begin{array}{c}-0.0293 \\
(0.236)\end{array}$ & $\begin{array}{c}0.0153^{*} \\
(1.879)\end{array}$ & $\begin{array}{c}-0.0228^{* * *} \\
(6.792)\end{array}$ & $\begin{array}{l}-0.2281^{* * *} \\
(3.795)\end{array}$ \\
\hline Lag (6) & - & $\begin{array}{r}-0.0083 \\
(1.408)\end{array}$ & $\begin{array}{c}-0.0167^{* *} \\
(3.507)\end{array}$ & $\begin{array}{c}-0.1820^{* *} \\
(2.418)\end{array}$ \\
\hline Lag (7) & - & $\begin{array}{l}-0.0338^{* * *} \\
(4.965)\end{array}$ & $\begin{array}{c}-0.0088^{*} \\
(1.895)\end{array}$ & $\begin{array}{c}-0.1112^{*} \\
(1.773)\end{array}$ \\
\hline Lag (8) & - & $\begin{array}{c}-0.0492^{* * *} \\
(5.668)\end{array}$ & - & - \\
\hline Lag (9) & - & $\begin{array}{l}-0.0420^{* * *} \\
(5.744)\end{array}$ & - & - \\
\hline Sum of lags & $\begin{array}{c}-0.9972^{* * *} \\
(4.113)\end{array}$ & $\begin{array}{c}-0.2931^{* * *} \\
(7.286)\end{array}$ & $\begin{array}{c}-0.1322^{* * *} \\
(5.822)\end{array}$ & $\begin{array}{c}-1.9465^{* * *} \\
(5.119)\end{array}$ \\
\hline $\begin{array}{l}\text { Code change } \\
\text { dummy }\end{array}$ & $\begin{array}{c}-0.0988^{* * *} \\
(8.221)\end{array}$ & & & \\
\hline Intercept & $\begin{array}{l}0.0576^{* * *} \\
(7.729)\end{array}$ & & & \\
\hline $\mathrm{R}^{2}$ & 0.7994 & & & \\
\hline Adjusted $\mathrm{R}^{2}$ & 0.7357 & & & \\
\hline AIC & -13.4990 & & & \\
\hline
\end{tabular}

Almon polynomial distributed lag (PDL) model; Dependent variable: 1-yr change in quarterly aggregate stock corporation bankruptcy rate; t-statistics in parentheses (HAC); reported coefficients ares; Sample period 1986Q1-2002Q4; Code change dummy: 0 from 1986Q1 to 1997Q4, 1 afterwards; AIC = Akaike Information Criterion; ${ }^{* * *}$ denotes significance at the $1 \%$ level; ${ }^{* *}$ denotes significance at the $5 \%$ level; ${ }^{*}$ denotes significance at the $10 \%$ level. 
variable adds little to model fit and forecast accuracy. Finally, we allow for the lag length of the PDL terms to differ to optimize fit. Compared to the model in Table 2, the in-sample fit is somewhat better and many more of the individual lag terms are significant.

The results of a vector error correction model (VECM) containing the same types of macroeconomic variables as in the Almon lag model of Table 2 are shown in Table 4. An important difference is the inclusion of the levels of respectively real GDP, the stock market index, the consumer price index and the corporate birth rate, to estimate a cointegrating equation (CE). ${ }^{8}$ The first column of Table 4 contains the coefficients of the $\mathrm{CE}$, which reflect the long term equilibrium relationship between the macroeconomic series and the aggregate bankruptcy rate. In the long run, higher levels of GDP are negatively related to bankruptcy rates and higher corporate birth rates are linked to higher bankruptcy rates, which does not seem unreasonable. The positive relationships between aggregate bankruptcies and the stock market index and consumer price index are, from an economic perspective, difficult to explain. However, the time series of the bankruptcy rate show that one could, ex post, draw trend lines with a slope (upward or downward) similar to the trend in the stock market over several sub-periods. This is also possible for the consumer price index. Such common trends over sub-periods could technically explain why the VEC model associates high levels of these macroeconomic variables with high bankruptcy rates. However the question remains about the economic meaning of these findings. These results may suggest that introducing the level of macroeconomic variables in prediction models may not always be appropriate. Contrary to their changes (i.e. inflation and stock market returns), index level variables likely contain a long history of increments/information that need not be relevant for firm failure. Although this extra information may help to increase in-sample fit, it may also cause spurious results, increase noise and reduce the quality of out-ofsample prediction. In fact, the findings in the next sub-section on forecasting are in line with this (potential) explanation. Finally, the error correction term has a significantly negative coefficient of -0.2427 , indicating that the aggregate bankruptcy rate reduces about $24 \%$ of its deviation from the long run equilibrium per quarter. By comparison, Vlieghe (2001) finds a very similar error correction term of -0.26 for a model using quarterly U.K. data for the period 1977-1999.

The right hand side columns of Table 4 show the short run dynamics of the error correction model (analogous to a VAR model). Short 
TABLE 4

Vector Error Correction Model I

\begin{tabular}{|c|c|c|c|c|c|}
\hline & \multicolumn{5}{|c|}{ VAR } \\
\hline & $\begin{array}{l}\text { Cointegrating } \\
\text { Equation (CE) }\end{array}$ & $\Delta(-1)$ & $\Delta(-2)$ & $\Delta(-3)$ & $\Delta(-4)$ \\
\hline Bankruptcy rate & - & $\begin{array}{l}-0.5167^{* * *} \\
(3.816)\end{array}$ & $\begin{array}{c}-0.6214^{* * *} \\
(4.367)\end{array}$ & $\begin{array}{c}-0.2806^{* *} \\
(2.073)\end{array}$ & $\begin{array}{l}-0.2511^{* *} \\
(2.318)\end{array}$ \\
\hline $\ln ($ real GDP) & $\begin{array}{l}-5.6425^{* * *} \\
(5.684)\end{array}$ & $\begin{array}{l}-2.1931^{* * *} \\
(2.741)\end{array}$ & $\begin{array}{r}0.6312 \\
(0.669)\end{array}$ & $\begin{array}{r}-1.0941 \\
(1.147)\end{array}$ & $\begin{array}{r}1.3251 \\
(1.512)\end{array}$ \\
\hline $\begin{array}{l}\text { In(Belgian All } \\
\text { Shares Index) }\end{array}$ & $\begin{array}{l}0.5431^{* * *} \\
(6.354)\end{array}$ & $\begin{array}{l}-0.1955^{* * *} \\
(4.161)\end{array}$ & $\begin{array}{l}-0.2250^{* * *} \\
(4.480)\end{array}$ & $\begin{array}{l}-0.2204^{* * *} \\
(4.487)\end{array}$ & $\begin{array}{l}-0.1203^{* * *} \\
(2.760)\end{array}$ \\
\hline $\begin{array}{l}\ln (\text { Consumer } \\
\text { Price Index })\end{array}$ & $\begin{array}{l}7.2959^{* * *} \\
(6.059)\end{array}$ & $\begin{array}{l}-2.5049^{* *} \\
(2.344)\end{array}$ & $\begin{array}{l}-3.8383^{* * *} \\
(3.978)\end{array}$ & $\begin{array}{c}-1.6287^{*} \\
(1.681)\end{array}$ & $\begin{array}{r}-0.7562 \\
(0.891)\end{array}$ \\
\hline Corporate birth rate & $\begin{array}{l}0.1509^{* * *} \\
(4.587)\end{array}$ & $\begin{array}{r}-0.0195 \\
(1.257)\end{array}$ & $\begin{array}{r}-0.0003 \\
(0.021)\end{array}$ & $\begin{array}{r}-0.0037 \\
(0.233)\end{array}$ & $\begin{array}{r}-0.0111 \\
(0.730)\end{array}$ \\
\hline Intercept $(\mathrm{CE})$ & 32.3813 & & & & \\
\hline Lag exclusion Wald test & & $91.554^{* * *}$ & $87.384^{* * *}$ & $73.817^{* * *}$ & $63.362^{* * *}$ \\
\hline Error correction term & $\begin{array}{l}-0.2427^{* * *} \\
(3.985)\end{array}$ & & & & \\
\hline $\begin{array}{l}\text { Code change dummy } \\
\text { (VAR) }\end{array}$ & $\begin{array}{l}-0.1056^{* * *} \\
(4.996)\end{array}$ & & & & \\
\hline Intercept (VAR) & 0.0996 & & & & \\
\hline $\mathrm{R}^{2}$ & 0.6479 & & & & \\
\hline Adjusted $\mathrm{R}^{2}$ & 0.4542 & & & & \\
\hline AIC & -13.6791 & & & & \\
\hline
\end{tabular}

Vector error correction model; Dependent variable: 1-yr change in quarterly aggregate stock corporation bankruptcy rate; Sample period 1986Q1-2002Q4; Code change dummy: 0 from 1986Q1 to 1997Q4, 1 afterwards; t-statistics in parentheses; Lag exclusion Wald test statistics are $\chi^{2}$ distributed; ${ }^{* * *}$ denotes significance at the $1 \%$ level; ${ }^{* *}$ denotes significance at the $5 \%$ level; ${ }^{*}$ denotes significance at the $10 \%$ level.

run dynamics are estimated for four lags (lag exclusion Wald tests point against including longer lag periods), and are in essence comparable to those found in the Almon lag model: lagged changes in real GDP growth, stock market returns, inflation and bankruptcy rates are negatively related to changes in aggregate bankruptcy rates. ${ }^{9}$ One major difference is that in the VECM short run changes in corporate birth rates are not significantly related to changes in the bankruptcy rate, although the sign remains negative. Table 5 shows the results of a more parsimonious VECM containing only bankruptcy rates, GDP, 
TABLE 5

Vector Error Correction Model II

\begin{tabular}{|c|c|c|c|}
\hline & \multicolumn{3}{|c|}{ VAR } \\
\hline & $\begin{array}{l}\text { Cointegrating } \\
\text { Equation }(\mathrm{CE})\end{array}$ & $\Delta(-1)$ & $\Delta(-2)$ \\
\hline Bankruptcy rate & - & $\begin{array}{c}-0.2581^{* *} \\
(2.425)\end{array}$ & $\begin{array}{c}-0.3079^{* * *} \\
(3.333)\end{array}$ \\
\hline $\ln ($ real GDP) & $\begin{array}{c}-1.2628^{*} \\
(1.737)\end{array}$ & $\begin{array}{c}-2.0388^{* *} \\
(2.643)\end{array}$ & $\begin{array}{c}1.1054 \\
(1.478)\end{array}$ \\
\hline $\ln ($ Consumer Price Index $)$ & $\begin{array}{l}2.8184^{* * *} \\
(3.2287)\end{array}$ & $\begin{array}{c}-1.4744^{*} \\
(1.693)\end{array}$ & $\begin{array}{c}-3.0605^{* * *} \\
(3.649)\end{array}$ \\
\hline Corporate birth rate & $\begin{array}{l}0.0520^{* *} \\
(2.243)\end{array}$ & $\begin{array}{r}-0.0209 \\
(1.411)\end{array}$ & $\begin{array}{r}-0.0027 \\
(0.183)\end{array}$ \\
\hline Intercept (CE) & -3.1591 & & \\
\hline Lag exclusion Wald tests & & $47.383^{* * *}$ & $37.332^{* * *}$ \\
\hline Error correction term & $\begin{array}{c}-0.2947^{* * *} \\
(4.545)\end{array}$ & & \\
\hline Code change dummy (VAR) & $\begin{array}{c}-0.0512^{* * *} \\
(4.944)\end{array}$ & & \\
\hline Intercept (VAR) & 0.0448 & & \\
\hline $\mathrm{R}^{2}$ & 0.5112 & & \\
\hline Adjusted $\mathrm{R}^{2}$ & 0.4207 & & \\
\hline AIC & -13.6861 & & \\
\hline
\end{tabular}

Vector error correction model; Dependent variable: 1-yr change in quarterly aggregate stock corporation bankruptcy rate; Sample period 1986Q1-2002Q4; Code change dummy: 0 from 1986Q1 to 1997Q4, 1 afterwards; t-statistics in parentheses; Lag exclusion Wald test statistics are $\chi^{2}$ distributed; ${ }^{* * *}$ denotes significance at the $1 \%$ level; ${ }^{* *}$ denotes significance at the $5 \%$ level; ${ }^{*}$ denotes significance at the $10 \%$ level.

CPI, and birth rates. The lag length is reduced to two, which greatly reduces the number of parameters in the system of equations. Both the long run and the short run dynamics of the model are comparable to those found in Table 4.

In addition to the models discussed above, we estimate a number of more straightforward alternatives - all estimated in first differences which all include an intercept and the code change dummy. Then in each model one of the following is added: (i) the lagged 12month real GDP growth, (ii) a distributed lag structure of the lagged 
12-month real GDP growth, (iii) the lagged 12-month change in the euro-zone CLI, (iv) a distributed lag structure of the lagged 12-month change in the euro-zone CLI, (v) the lagged 12-month stock market performance, and (vi) a distributed lag structure of the lagged 12month stock market performance. The final alternative we consider is an ARMA model. ${ }^{10}$ The fit statistics of all these models for our 1986Q1-2002Q4 sample period are summarized in Table 6.

TABLE 6

Comparison of Model Fit

\begin{tabular}{lccc}
\hline & $\mathrm{R}^{2}$ & Adjusted $\mathrm{R}^{2}$ & $\mathrm{AIC}$ \\
\hline Almon lag model I & 0.7836 & 0.6925 & -13.3143 \\
Almon lag model II & 0.7994 & 0.7357 & -13.4990 \\
VECM I & 0.6479 & 0.4542 & -13.6791 \\
VECM II & 0.5112 & 0.4207 & -13.6861 \\
Lagged 12-month real GDP growth & 0.2273 & 0.2019 & -12.5151 \\
Real GDP growth (DL) & 0.3340 & 0.2847 & -12.6616 \\
Lagged 12-month change in & & & \\
$\quad$ the euro-zone CLI & 0.3503 & 0.3290 & -12.6885 \\
Euro-zone CLI (DL) & 0.4453 & 0.4042 & -12.8445 \\
Lagged 12-month stock & & & \\
$\quad$ market performance & 0.3425 & 0.3206 & -12.7432 \\
Stock market performance (DL) & 0.4879 & 0.4470 & -12.8894 \\
ARMA & 0.6648 & 0.6478 & -13.3852 \\
\hline
\end{tabular}

Fit statistics of models of 1-yr change in quarterly aggregate stock corporation bankruptcy rate; Sample period 1986Q1-2002Q4; AIC = Akaike Information Criterion; Almon lag model I: cf. Table 2; Almon lag model II: cf. Table 3; VECM I: cf. Table 4; VECM II: cf. Table 5; Lagged 12-month real GDP growth: least squares regression model consisting of the 1-period lagged 12-month real GDP growth, an intercept and the code change dummy; Real GDP growth (DL): Almon lag model consisting of a polynomial distributed lag structure of the 12-month real GDP growth, an intercept and the code change dummy; Lagged 12-month change in the euro-zone CLI: least squares regression model consisting of the 1-period lagged 12-month change in the OECD euro-zone Composite Leading Indicator, an intercept and the code change dummy; Euro-zone CLI (DL): Almon lag model consisting of a polynomial distributed lag structure of the 12-month change in the OECD euro-zone Composite Leading Indicator, an intercept and the code change dummy; Lagged 12-month stock market performance: least squares regression model consisting of the 1-period lagged 12-month stock market performance (based on the Belgian All Shares Index), an intercept and the code change dummy; Stock market performance (DL): Almon lag model consisting of a polynomial distributed lag structure of the 12-month stock market performance (based on the Belgian All Shares Index), an intercept and the code change dummy; ARMA: ARMA model, including the code change dummy. 
First, the model fit in terms of $\mathrm{R}^{2}$ for all models is quite high, especially given the fact that they are estimated in differences. Because of the large number of parameters, the adjusted $\mathrm{R}^{2} \mathrm{~s}$ of the more complex models are substantially lower than their $\mathrm{R}^{2}$ (especially for the VECMs). This already points to one of the main potential weaknesses of the Almon lag and the VEC models: given the limited number of observations available in a typical macroeconomic time series analysis, these types of models tend to be overspecified. In this respect, it is important to note that our test sample period length of 17 years (i.e. 68 quarters, extended up to 20 years or 80 quarters in the next subsection) is comparable to that of other studies in the literature. ${ }^{11}$ In terms of adjusted $\mathrm{R}^{2}$, a model containing only a distributed lag term of the stock market performance does almost equally well as the VECM in Table 4 (VECM I) and better than the VECM in Table 5 (VECM II). The adjusted $\mathrm{R}^{2}$ of the ARMA model is substantially higher than that of the VECMs, and is second only to that of the Almon lag models. According to the Akaike Information Criterion (AIC), however, the VECMs provide the best fit of all the alternatives. Again, a note of caution is needed, as the AIC has a propensity for selecting overfit models (Bengtsson and Cavanaugh (2006)). If overspecification is a problem, good in-sample fit will not necessarily lead to strong out-of-sample forecasting abilities.

\section{B. Forecasting the aggregate bankruptcy rate}

In the remainder of the paper we use the models described in the previous subsection to produce quarterly repeated series of out-of-sample forecasts of the annual aggregate bankruptcy rate ${ }^{12}$ for the period 2002Q4 to 2005Q4. In practice, the base models (data up to 2002Q4) are used to forecast aggregate bankruptcy rates for the period 2003Q12003Q4. Next, the sample period is extended by one quarter to include 2003Q1, all models are re-estimated and the new models are used to construct a forecast for the period 2003Q2-2004Q1. This procedure is repeated until 2005Q4, when forecasts for 2006Q1 to 2006Q4 are made. All forecasts are based on dynamic-stochastic simulations $(1,000$ times repeated), which take into account that the future values of the explanatory variables needed to construct four quarter forecasts are uncertain. As a benchmark, we include a naïve (random walk) forecast strategy, viz. the lagged 12-month bankruptcy rate. In other words, for example, the naïve forecast for the aggregate bankruptcy rate for 
2005Q1-2005Q4 is the observed bankruptcy rate for 2004Q1-2004Q4 (cf. Hillegeist et al.(2004)).

The accuracy of the twelve series of forecasts (i.e. the eleven models + the naïve strategy) is compared in Table 7. We report three of the most frequently used measures of forecast accuracy: the mean absolute percentage error (MAPE), the mean squared error (MSE) and the modified Theil coefficient of inequality (Theil U), which is the root mean squared error (RMSE) of the model forecasts relative to the RMSE of the naïve forecasts. One of the main differences between the accuracy measures is that MSE and Theil U 'penalize' large forecast errors more than MAPE. The most striking result in Table 7 is that the Almon lag model from Table 2 (Almon lag model I) has the best forecast accuracy based on MSE and Theil U (and the third best accuracy according to MAPE), while VECM I has the worst forecast performance of all twelve alternatives. In fact, VECM I results in poorer forecasts of the aggregate bankruptcy rates than the naïve strategy, which is ranked eleventh according to all three criteria. The MAPE shows that the average aggregate bankruptcy rate forecast based on VECM I is off by $12.07 \%$, compared to only $5.46 \%$ for Almon lag model I and $4.89 \%$ for Almon lag model II based forecasts. The more parsimonious VECM II appears to suffer less from overfitting and does somewhat better than the naïve strategy and VECM I, although it is still among the worst performing models. The single macroeconomic variable models all perform about equally well and lead to lower forecast errors than the naïve strategy. The lagged stock market performance even has the lowest MAPE of all but one, which is likely to explain the importance of this variable in the Almon lag models. The ARMA model does quite well, with a relative rank of two for MSE and Theil $\mathrm{U}$ and four for MAPE.

As an extension of the comparison, formal test results of the hypothesis of no difference in the unconditional forecast accuracy of two forecasts are reported in Table 8. However, it should be noted that the small forecast sample size is likely to limit the power of the tests. We report one parametric (Diebold-Mariano test; see Diebold and Mariano (1995)) and one non-parametric test (Wilcoxon signed rank test). All forecast errors are compared to those of the naïve strategy and those of VECM I. According to the Diebold-Mariano test (which takes into account potential heteroskedasticity and autocorrelation in the forecast errors), only the lagged 12-month real GDP growth does significantly better than the naïve strategy. ${ }^{13}$ The Wilcoxon signed rank 
TABLE 7

Comparison of Forecast Accuracy

\begin{tabular}{lccc}
\hline & MAPE & MSE & Theil U \\
\hline Lagged 12-month bankruptcy rate & 10.7945 & 0.0180 & 1.0000 \\
& $(11)$ & $(11)$ & $(11)$ \\
Almon lag model I & 5.4566 & 0.0050 & 0.5268 \\
& $(3)$ & $(1)$ & $(1)$ \\
Almon lag model II & 4.8942 & 0.0071 & 0.6299 \\
& $(1)$ & $(3)$ & $(3)$ \\
VECM I & 12.0729 & 0.0246 & 1.1677 \\
& $(12)$ & $(12)$ & $(12)$ \\
VECM II & 9.1181 & 0.0151 & 0.9166 \\
& $(9)$ & $(10)$ & $(10)$ \\
Lagged 12-month real GDP growth & 7.8148 & 0.0088 & 0.6997 \\
& $(5)$ & $(6)$ & $(6)$ \\
Real GDP growth (DL) & 8.2568 & 0.0099 & 0.7414 \\
& $(8)$ & $(7)$ & $(7)$ \\
Lagged 12-month change & 9.4685 & 0.0138 & 0.8744 \\
in the euro-zone CLI & $(10)$ & $(9)$ & $(9)$ \\
Euro-zone CLI (DL) & 7.8221 & 0.0099 & 0.7419 \\
& $(6)$ & $(8)$ & $(8)$ \\
Lagged 12-month stock & 5.3906 & 0.0086 & 0.6900 \\
market performance & $(2)$ & $(4)$ & $(4)$ \\
Stock market performance (DL) & 7.9596 & 0.0087 & 0.6937 \\
& $(7)$ & $(5)$ & $(5)$ \\
ARMA & 6.3292 & 0.0069 & 0.6230 \\
& $(4)$ & $(2)$ & $(2)$ \\
\hline
\end{tabular}

Forecast accuracy measures of out-of-sample 1-yr forecasts of the aggregate stock corporation bankruptcy rate, repeated each quarter with model re-estimation from 2002Q4 to 2005Q4 (forecast sample period: 2003Q1-2006Q4); Forecasts based on dynamic-stochastic simulations $(1,000$ times repeated); MAPE $=$ Mean Absolute Percentage Error; MSE $=$ Mean Squared Error; Theil U = Modified Theil Coefficient of Inequality $=($ Root MSE of the model)/(Root MSE of the naïve forecast); Lagged 12-month bankruptcy rate: naïve (random walk) forecast; Almon lag model I: cf. Table 2; Almon lag model II: cf. Table 3; VECM I: cf. Table 4; VECM II: cf. Table 5; Lagged 12-month real GDP growth: least squares regression model consisting of the 1-period lagged 12-month real GDP growth, an intercept and the code change dummy; Real GDP growth (DL): Almon lag model consisting of a polynomial distributed lag structure of the 12-month real GDP growth, an intercept and the code change dummy; Lagged 12-month change in the euro-zone CLI: least squares regression model consisting of the 1-period lagged 12-month change in the OECD euro-zone Composite Leading Indicator, an intercept and the code change dummy; Euro-zone CLI (DL): Almon lag model consisting of a polynomial distributed lag structure of the 12-month change in the OECD euro-zone Composite Leading Indicator, an intercept and the code change dummy; Lagged 12-month stock market performance: least squares regression model consisting of the 1-period lagged 12-month stock market performance (based on the Belgian All Shares Index), an intercept and the code change dummy; Stock market performance (DL): Almon lag model consisting of a polynomial distributed lag structure of the 12-month stock market performance (based on the Belgian All Shares Index), an intercept and the code change dummy; ARMA: ARMA model, including the code change dummy; relative rankings in parentheses. 
TABLE 8

Forecast Accuracy Comparison Tests

\begin{tabular}{lcccc}
\hline & \multicolumn{2}{c}{$\begin{array}{c}\text { Diebold - } \\
\text { Mariano Test }\end{array}$} & \multicolumn{2}{c}{$\begin{array}{c}\text { Wilcoxon Signed } \\
\text { Rank Test }\end{array}$} \\
\cline { 2 - 5 } & $\begin{array}{c}\text { Versus } \\
\text { lagged 12-m } \\
\text { bankruptcy } \\
\text { rate }\end{array}$ & $\begin{array}{c}\text { Versus } \\
\text { VECM }\end{array}$ & $\begin{array}{c}\text { Versus } \\
\text { lagged 12-m } \\
\text { bankruptcy } \\
\text { rate }\end{array}$ & $\begin{array}{c}\text { Versus } \\
\text { VECM }\end{array}$ \\
\hline Almon lag model I & -1.4905 & $-3.4275^{* * *}$ & $1.8170^{*}$ & $2.7255^{* * *}$ \\
Almon lag model II & -0.9837 & $-3.2708^{* * *}$ & 1.3278 & $2.9352^{* * *}$ \\
VECM I & 0.6204 & - & 0.6290 & - \\
VECM II & -0.5434 & -1.0418 & 0.6989 & 1.1182 \\
Lagged 12-month real GDP growth & $-1.7827^{*}$ & $-2.4028^{* *}$ & $2.0966^{* *}$ & $2.3062^{* *}$ \\
Real GDP growth (DL) & -1.2429 & $-2.2327^{* *}$ & $1.6772^{*}$ & $1.8869^{*}$ \\
Lagged 12-month change & & & & \\
$\quad$ in the euro-zone CLI & -0.5509 & $-2.2220^{* *}$ & 0.8386 & $1.8170^{*}$ \\
Euro-zone CLI (DL) & -1.2708 & $-2.8357^{* *}$ & $1.8170^{*}$ & $2.4460^{* *}$ \\
Lagged 12-month stock market & & & & \\
$\quad$ performance & -0.8107 & $-3.0179^{* *}$ & 1.1881 & $2.7954^{* * *}$ \\
Stock market performance (DL) & -1.2199 & $-2.2160^{* *}$ & 1.5375 & $1.7471^{*}$ \\
ARMA & -1.3147 & $-2.4812^{* *}$ & 1.6074 & $2.0267^{* *}$ \\
\hline
\end{tabular}

Test for equality of forecast errors of out-of-sample 1-yr forecasts of the aggregate stock corporation bankruptcy rate, repeated each quarter with model re-estimation from 2002Q4 to 2005Q4 (forecast sample period: 2003Q1-2006Q4); Forecasts based on dynamic-stochastic simulations (1,000 times repeated); Diebold-Mariano test: see Diebold and Mariano (1995); Lagged 12-month bankruptcy rate: naïve (random walk) forecast; Almon lag model I: cf. Table 2; Almon lag model II: cf. Table 3; VECM I: cf. Table 4; VECM II: cf. Table 5; Lagged 12-month real GDP growth: least squares regression model consisting of the 1-period lagged 12-month real GDP growth, an intercept and the code change dummy; Real GDP growth (DL): Almon lag model consisting of a polynomial distributed lag structure of the 12-month real GDP growth, an intercept and the code change dummy; Lagged 12 -month change in the euro-zone CLI: least squares regression model consisting of the 1-period lagged 12-month change in the OECD euro-zone Composite Leading Indicator, an intercept and the code change dummy; Euro-zone CLI (DL): Almon lag model consisting of a polynomial distributed lag structure of the 12-month change in the OECD euro-zone Composite Leading Indicator, an intercept and the code change dummy; Lagged 12-month stock market performance: least squares regression model consisting of the 1period lagged 12-month stock market performance (based on the Belgian All Shares Index), an intercept and the code change dummy; Stock market performance (DL): Almon lag model consisting of a polynomial distributed lag structure of the 12-month stock market performance (based on the Belgian All Shares Index), an intercept and the code change dummy; ARMA: ARMA model, including the code change dummy; ${ }^{* * *}$ denotes significance at the $1 \%$ level; ${ }^{* *}$ denotes significance at the $5 \%$ level; ${ }^{*}$ denotes significance at the $10 \%$ level. 
test also rejects the null hypothesis of no difference in forecast accuracy for Almon lag model I and the real GDP growth distributed lag model. Both tests find significant differences between the forecast accuracy of the VECM and all other alternatives, except for the naïve strategy. Further tests (not reported in Table 8) show that there are no significant differences in the forecast errors of the Almon lag models and some of the more parsimonious alternatives, such as the ARMA or the lagged 12-month real GDP growth models.

\section{CONCLUSIONS}

We estimated eleven different model specifications to explain changes in the Belgian aggregate stock corporation bankruptcy rate - which is a proxy for aggregate default risk or systematic probability of default over the period 1986-2002: two Almon lag models and two Vector Error Correction Models (VECMs) containing multiple macroeconomic variables, six simpler specifications based on only one macroeconomic series (lagged real GDP growth, a distributed lag model of the real GDP growth, lagged changes in the euro-zone Composite Leading Indicator, a distributed lag model of changes in the euro-zone Composite Leading Indicator, lagged stock market return and a distributed lag model of the stock market return) and, finally, an ARMA model. Out-of-sample forecasts for the period 2003-2006 based on these models were compared to a naïve random walk forecast. Most models give rise to smaller forecast errors than the naïve forecast strategy. A notable exception to this is one of the VECMs, which has a good in sample fit but performs very badly in the out-of-sample forecasts, indicating that this type of model is likely to be overspecified for the problem at hand. An Almon lag model with the same explanatory variables does much better, both in-sample and out-of-sample. Overall our results indicate that simple models perform very well relative to more extensive ones when forecasting is concerned: the extra information the latter constructs contain may improve in-sample fit but also tends to introduce extra noise in out-of-sample prediction.

\section{NOTES}

1. Macroeconomic risk can be reduced through international portfolio diversification, although the increasing interdependencies in the global economy are likely to make this more difficult (see e.g. Pesaran et al. (2006)). 
2. It should be noted that comparison of failure rates across countries is not straightforward because of the differences in legal systems, regulations, the type of companies which are included in official statistics, etc. Statistics from business sources (e.g. Graydon Belgium or Euler Hermes) therefore show a very broad range of bankruptcy rates (roughly between $0.2 \%$ and $3 \%$ p.a. for 2005). Still, the available academic evidence - of which there is very little - seems to indicate that Belgian bankruptcy rates are about average for Western Europe. The average annual bankruptcy rate during the 1990s of the 12 Western European countries with meaningful statistics in Claessens and Klapper's (2005) study is $2.55 \%$. For Belgium they report $2.59 \%$.

3. In general, the term 'aggregate bankruptcy rate' relates to the relative number of bankruptcies for all companies active in the economy or for all companies of a certain type, 'aggregate default rate' is used in the context of bond portfolios or bank loan portfolios, while 'aggregate failure rates' is a more general expression which is used throughout the literature as a synonym for either 'aggregate bankruptcy rate' or 'aggregate default rate' depending on the research topic of the paper.

4. This rather strict definition of the aggregate failure rate could be expanded by including, for instance, voluntary liquidations or formal reorganization cases. However, this is not straightforward. Voluntary liquidation procedures are not necessarily an alternative for bankruptcies. In some voluntary liquidations all (or almost all) creditors of the liquidating company are paid in full, which means that the liquidation value of the company's assets is larger than that of its liabilities, or that the shareholders agree to make up for the difference. In these cases, there is no real default. Insolvent companies can use the voluntary liquidation procedure as an alternative for bankruptcy ('deficitaire vereffening') but only if strict conditions are met. If it is judged that the procedure is only used to avoid bankruptcy, the Commercial Court can terminate the voluntary liquidation and transfer the company to the bankruptcy procedure. A bankruptcy verdict can also be demanded by the Public Prosecutor's Office. These bankruptcy cases are captured by our definition of the failure rate. As the corporate event database does not allow distinguishing between solvent and insolvent voluntary liquidations, including voluntary liquidations may introduce considerable noise in the failure rate proxy.

An alternative extension of the failure rate definition would be the inclusion of reorganization procedure cases. However, reorganization is not used very frequently: the 'reorganization rate' (i.e. the proportion of initiated reorganization procedures to the sum of all started bankruptcy procedures) in Belgium is less than $2 \%$. There are also some arguments against including these procedures in the aggregate failure rate. First, if a reorganization procedure succeeds, the company continues as going concern or is taken over and hence should not captured by our failure rate variable. If the reorganization procedure fails (which is often the case in practice), the company typically moves into the liquidation bankruptcy procedure, which implies that it is then incorporated in the aggregate failure rate. For the latter companies, extending the failure rate's definition to include formal reorganizations therefore only leads to a difference in timing (i.e. they have to be included in the quarter they filed for reorganization, instead of in the quarter they filed for a liquidation procedure).

5. Although some previous studies find links between the exchange rate and default rates, this does not seem to be the case in our sample period. We find no significant relationship between the SDR or USD exchange rate and aggregate failures. This may not be surprising considering that much of the international trade of Belgian companies is conducted within the euro-zone. Indirect effects of the exchange rate on the competitiveness of Belgian companies in the global economy are likely to be also captured by the real GDP growth variable. Therefore, we do not further explore exchange rate variables in this paper. 
6. It goes without saying that the different macroeconomic series are to some extent correlated through time (cross-correlograms available upon request).

7. Not reported; available upon request.

8. Both the trace and the maximum eigenvalue test scores of Johansen cointegration rank tests indicate the order of cointegration, $r$, is equal to 3 . This is the case for the five variables in the model in Table 4, as well as for the four variables in the model in Table 5. As $r$ is higher than one, we use the first eigenvector (based on the largest eigenvalue) and normalize w.r.t. the coefficient of the dependent variable, following, for instance, Maysami and Koh (2000).

9. Only results for changes in aggregate bankruptcy rates are reported. Short term dynamics for the other variables are available upon request.

10. Based on fit criteria, a specification with an $\mathrm{AR}(1)$ and an MA(4) term was selected.

11. For example, Vlieghe (2001) uses 23 years of quarterly data, Altman (1983) 26 years of quarterly data, Hudson (1986) 32 years of annual data, and Pesaran et al. (2004) and Pesaran et al. (2006) 18 years of quarterly data.

12. The choice for annual forecasts is made because the literature on probability of default typically focuses on one year periods.

13. A negative sign for the Diebold-Mariano test indicates, for instance, that the mean squared forecast error of the naïve strategy is larger than mean squared forecast error of the ARMA model.

\section{REFERENCES}

Allen, L. and Saunders, A., 2004, Incorporating Systemic Influences Into Risk Measurements: a Survey of the Literature, Journal of Financial Services Research 26, 2, 161-192.

Altman, E.I., 1968, Financial Ratios, Discriminant Analysis and the Prediction of Corporate Bankruptcy, Journal of Finance 23, 4, 589-609.

Altman, E.I., 1983, Why Businesses Fail, Journal of Business Strategy 3, 4, 15-21.

Bengtsson, T. and Cavanaugh, J.E., 2006, An Improved Akaike Information Criterion for State-Space Model Selection, Computational Statistics \& Data Analysis 50, 2635-2654.

Bhattacharjee, A., Higson, C., Holly, S. and Kattuman, P., 2005, Macroeconomic Instability and Corporate Failure, Working Paper (University of Cambridge).

Boyes, W.J. and Faith, R.L., 1986, Some Effects of the Bankruptcy Reform Act of 1978, Journal of Law and Economics 29, 139-149.

Chen, J.-H. and Williams, J., 1999, The Determinants of Business Failures in the US LowTechnology and High-Technology Industries, Applied Economics 31, 1551-1563.

Claessens, S. and Klapper, L.F., 2005, Bankruptcy around the World: Explanations of Its Relative Use, American Law and Economics Review 7, 1, 253-283.

Cuthbertson, K. and Hudson, J., 1996, The Determinants of Compulsory Liquidations in the UK, The Manchester School of Economic and Social Studies 64, 3, 298-308.

Dewaelheyns, N. and Van Hulle, C., 2008, Legal Reform and Aggregate Small and Micro Business Bankruptcy Rates: Evidence from the 1997 Belgian Bankruptcy Code, Small Business Economics, forthcoming.

Diebold, F.X. and Mariano, R.S., 1995, Comparing Predictive Accuracy, Journal of Business \& Economic Statistics 13, 3, 253-263.

Domowitz, I. and Eovaldi, T.L., 1993, The Impact of the Bankruptcy Reform Act of 1978 on Consumer Bankruptcy, Journal of Law and Economics 36, 803-835.

Drehmann, M., Patton, A.J. and Sorensen, S., 2006, Corporate Defaults and Macroeconomic Shocks: Non-Linearities and Uncertainty, Working Paper (Bank of England).

Duffie, D., Saita, L. and Wang, K., 2007, Multi-Period Corporate Default Probabilities with Stochastic Covariates, Journal of Financial Economics 83, 3, 635-665.

Enders, W., 1995, Applied Econometric Time Series, (Wiley, New York). 
Fisher, T.C.G. and Martel, J., 2003, The Effect of Bankruptcy Reform on the Number of Corporate Reorganization Proposals, Canadian Public Policy 29, 3, 339-350.

Gaffeo, E. and Santoro, E., 2006, Macroeconomic Conditions and Business Failures in Italy: a Panel Cointegration Approach, Working Paper (University of Trento).

Graydon Belgium, 2002, Hernieuwde Enquête bij Gefailleerden, Graydon Studie 50.

Graydon Belgium, 2003, Resultaten van een Enquête bij de Rechters-Commissarissen, Graydon Studie 68.

Gujarati, D.N., 1995, Basic Econometrics, 3rd Edition, (McGraw-Hill, New York).

Helwege, J. and Kleiman, P., 1997, Understanding Aggregate Default Rates of High Yield Bonds, Journal of Fixed Income 7, 1, 55-62.

Hillegeist, S.A., Keating, E.K., Cram, D.P. and Lundstedt, K.G., 2004, Assessing the Probability of Bankruptcy, Review of Accounting Studies 9, 5-34.

Hudson, J., 1986, An Analysis of Company Liquidations, Applied Economics 18, 219-235.

Hudson, J., 1997, Company Bankruptcies and Births Matter, Applied Economics 29, 647654.

Hunter, J. and Isachenkova, N., 2006, Aggregate Economy Risk and Company Failure: An Examination of UK Quoted Firms in the Early 1990s, Journal of Policy Modeling 28, 911-919.

Ilmakunnas and P., Topi, J., 1999, Microeconomic and Macroeconomic Influences on Entry and Exit of Firms, Review of Industrial Organization 15, 283-301.

Johnson, P. and Parker, S., 1994, The Interrelationships between Births and Deaths, Small Business Economics 6, 4, 283-290.

Koopman, S.J. and Lucas, A., Business and Default Cycles for Credit Risk, 2005, Journal of Applied Econometrics 20, 311-323.

Liu, J., 2004, Macroeconomic Determinants of Corporate Failures: Evidence from the UK, Applied Economics 36, 939-945.

Liu, J. and Wilson, N., 2002, Corporate Failure Rates and the Impact of the 1986 Insolvency Act: an Econometric Analysis, Managerial Finance 28, 6, 61-71.

Maysami, R.C. and Koh, T.S., 2000, A Vector Error Correction Model of the Singapore Stock Market, International Review of Economics and Finance 9, 79-96.

McDonald, C.G. and Van de Gucht, L.M., 1997, High-Yield Bond Default and Call Risks, Review of Economics and Statistics 81, 3, 409-419.

Nelson, J.P., 2000, Consumer Bankruptcy and the Bankruptcy Reform Act: A Time-Series Intervention Analysis, 1960-1997, Journal of Financial Services Research 17, 2, 181200.

Ohlson, J.A., 1980, Financial Ratios and the Probabilistic Prediction of Bankruptcy, Journal of Accounting Research 18, 1, 109-131.

Perron, P., 1989, The Great Crash, the Oil Price Shock, and the Unit Root Hypothesis, Econometrica 57, 6, 1361-1401.

Pesaran, M.H., Schuermann, T., Treutler, B.-J. and Weiner, S.M., 2006, Macroeconometric Dynamics and Credit Risk: a Global Perspective, Journal of Money, Credit, and Banking 38, 5, 1211-1262.

Peterson, R.A., Kozmetsky, G. and Ridgway, N.M., 1983, Perceived Causes of Small Business Failures: A Research Note, American Journal of Small Business 8, 1, 15-19.

Sullivan, T.A., Warren, E. and Westbrook, J., 1999, Financial Difficulties for Small Businesses and Reasons for Their Failure, US Small Business Administration Office of Advocacy Research Study 188.

Turner, P., Coutts, A. and Bowden, S., 1992, The Effect of the Thatcher Government on Company Liquidations: an Econometric Study, Applied Economics 24, 935-943.

Vlieghe, G.W., 2001, Indicators of Fragility in the UK Corporate Sector, Bank of England Working Paper 146.

Wadhwani, S.B., 1986, Inflation, Default Premia and the Stock Market, The Economic Journal 96, 120-138. 
